\title{
12
}

\section{Teachers' Memories and the Cold War: Introduction to Part II}

\section{Robert Thorp and Barbara Christophe}

The texts in this section of the volume address the complex and interesting question of how history teachers' personal memories and experiences of the past interact with their perceptions of historical events and a broader historical culture. Generally speaking, there are three different elements at play here that alone and combined provide a rich and challenging field for research into memory practices and history education.

History itself is a vague notion with various connotations. Academic history, often regarded as the gold standard in history education, is commonly separated from the past and memory through its focus on critical

R. Thorp $(\bowtie)$

University of Stockholm, Stockholm, Sweden

The University of Newcastle, Newcastle, NSW, Australia

e-mail: robert.thorp@edu.su.se; robert.thorp@newcastle.edu.au

B. Christophe

Georg Eckert Institute for International Textbook Research, Member of the Leibniz Association, Brunswick, Germany e-mail: christophe@gei.de 
methodological inquiry (Lévesque 2008; Parkes 2011; Wilschut 2012; Wineburg 2001). In this sense, academic history presupposes distance towards the past since it asks us to disregard what we cannot ground in reliable sources from it; history is regarded as the reconstruction of past events. Questions of truth, methodology and reliability become central here. Still, history also plays a central and fundamental role in the everyday perceptions we have of ourselves, of our communities and of the world at large. Accordingly, questions of identity and worldview become pivotal. It is thus not only methodological rigor and academic procedure, but also cultural aspects that heavily affect how we approach the past and history itself, as the three texts in this section will show.

History, academic and public alike, can thus be argued to share one crucial feature with memory. Both are culturally contingent, both cater to who we are and to what we perceive as meaningful at a very basic level. In this sense, all of us, including academic historians and professionally trained history teachers, can be seen as performing memory practices; that is, culturally informed ways of remembering, perceiving and making sense of the past and of history. This means that we never encounter or approach history from a neutral point of view and that history and our perceptions thereof are always contextually contingent.

With this view, you could argue that a kind of cultural self-awareness becomes central to how we approach and make sense of history, rather than whether we apply a critical methodology to the sources from the past that we have at hand. However, and this is rather crucial, much of what we know about history may be implicit and more or less taken for granted and therefore difficult to scrutinize critically, an aspect highlighted by the notion of memory practices. In this sense, history could be perceived as entangled between serious academic study, personal memories, and broader cultural and ideological aspects of the past (Thorp 2016).

If we take these aspects into account it can be argued that history education becomes a rather complex enterprise. History teachers are individuals, each with a personal relationship with history, who at the same time have been trained to approach this history with distance and scrutiny. Furthermore, history teachers are expected to comply with curricular demands and to further what could be called ideological aims whenever 
they carry out their teaching. This can prove to be a rather challenging task as teachers have to navigate between what may be conflicting concerns in their profession. In addition, history carries a normative load through which we position ourselves ideologically, which may prove to be a further challenge when teaching (Persson 2017; Persson and Thorp 2017). In line with new trends in memory research, recent work in history education has highlighted these entanglements. Studies have shown how cultural contingencies affect history education and feed into how teachers and students perceive history at a very basic level (Boutonnet 2013; Persson 2017; Persson and Thorp 2017; Porat 2004; Thorp 2016; Wineburg, Mosborg, Porat and Duncan 2007; Zanazanian 2012). The three texts in this section should be regarded as a further exploration of this field.

\section{Three Case Studies}

Barbara Christophe's contribution to this section focuses on how teachers respond to ambivalence as a characteristic feature of postmodern memory cultures, the traces of which we can even find in current history textbooks. Providing a microanalysis of a textbook quotation on the origin of the Cold War from a German textbook, she shows how ambivalence is created by blending elements from rival traditions of explaining the conflict. Comparing how teachers from Germany and Switzerland read and assess this ambivalent and therefore rather typical quotation she arrives at three conclusions. First of all, teachers not only understand the same lines rather differently; they also judge them from different positions. Whereas Swiss teachers argue mostly in line with the traditionalist concept of a morally superior USA and a dictatorial Soviet Union, German teachers are much more divided among themselves, with some adhering to revisionist, others to traditionalist interpretations. Furthermore, especially among German teachers leaning towards revisionist positions, we find clear differences between those trained in former East Germany and those trained on the west side of the Wall. While West German teachers tend to express moral criticism of the USA, their East German counterparts criticise moralising views on history and normalise Soviet expansionism. 
Finally, every teacher perceives his or her own interpretation of the textbook account to be the only legitimate one, thus contributing to what Christophe calls the 'illusion of hegemony', the assertion that there is one legitimate way of explaining the Cold War. Discussing her empirical findings in the light of competing theoretical considerations about the social function of ambivalence, Christophe argues that a productive engagement with ambivalence as discussed in memory studies is hampered by this illusion of hegemony.

Eva Fischer's text further explores the complex interplay and entanglement between teachers' personal experiences and professional role and focuses on how a teacher from the former GDR deals with textbook narrations about the Cold War. Guided by the question as to how people with twofold horizons of experience perceive current discourses on memory culture and how they position themselves towards those discourses, Fischer explicitly focuses on a person who, born in 1956, is old enough to have worked in the GDR and young enough to have continued her profession in reunited Germany. With recourse to methodological instruments developed by James Wertsch, Fischer analyses the stances taken by the teacher in three differently structured situational contexts: during a biographical narrative interview, a guided interview, and two videorecorded history lessons. She identifies four recurring narrative patterns mobilised by the teacher in order to build a bridge between the old narratives she grew up with in the GDR and the new narratives she feels she should use in her teaching today. The teacher (i) constructs parallels between family-related and national experiences, (ii) describes members of her family, despite their closeness to the GDR regime, as victims of national separation, (iii) narrates encounters between East and West as stories of reconciliation, and (iv) describes the West as slowly catching up with a morally superior East. The tensions and contradictions between these four narrative patterns are managed by a narrative and argumentative style which creates ambivalence and avoids the assignment of responsibility for certain actions. Fischer concludes that this teacher, who tries to narrate the story of her life in the GDR in accordance with what she perceives to be the dominant Western narrative as a sad story of separation and victimisation, enacts a kind of tacit resistance to the same Western narrative of the Cold War in class by pointing, for example, to 
the moral superiority the political East enjoyed - in her eyes - over the political West.

Nadine Ritzer's study of how the broader cultural understanding of two key events of the Cold War, the Prague spring of 1968 and the Vietnam War, has evolved in Switzerland relies upon contemporary teaching journals of the period, older and modern history textbooks, and interviews with teachers. She thus does two things at the same time: She examines the subject from a position of present-day memory politics and she employs a diachronic perspective, enabling her to study discursive shifts. Ritzer's study arrives at a number of interesting results. She demonstrates that Swiss political neutrality has always leaned ideologically towards the West and that, despite several approaches showing signs of differentiation, a fundamental anti-communist consensus continues to ensure that bipolar frames of interpretation dominate textbooks. She shows that the textbooks studied do not delve deeper into the transnational significance of the year 1968, despite the fact that even contemporary witnesses point out that neither the Prague Spring nor the Vietnam War could be solely explained in terms of East-West opposition. Interestingly, the study reveals that, although the same books are generally critical of the role of the USA in the war, most of them implicitly legitimize atrocities such as the My Lai Massacre by explaining them with reference to the domino effect or the guerrilla tactics of the Vietcong. Ritzer also illustrates how the Vietnam War is regularly used in Swiss textbooks as an example of a proxy war between capitalism and communism, whilst omitting the North-South themes accentuated by recent research. Finally she elucidates how teachers regularly deviate from the textbooks' interpretation, for instance by categorising the Vietnam War as a 'third-world problem'.

\section{Concluding Comments}

Taken together, the three contributions in this section stress the importance of broader cultural, societal and situational aspects as key to understanding the complexities and challenges that go along with history education as one field where we can observe the unfolding of memory 
practices. The Cold War topic is shown to be heavily entangled between individuals' memories, ideological concerns, personal preferences, and broader social concerns. At the same time, the three authors render visible that culturally shared narratives as conveyed in textbooks, for instance, determine memory practices of individuals to different extents. As we have seen, teachers can chose to reproduce, to reject or to appropriate them with creativity. Furthermore, their choices can vary in differently structured situations.

\section{References}

Boutonnet, V. 2013. Les ressources didactiques: typologie d'usages en lien avec la méthode historique et l'intervention éducative d'enseignants d'histoire au secondaire. Montréal: Université de Montréal.

Lévesque, S. 2008. Thinking Historically: Educating Students for the Twenty-first Century. Toronto: Buffalo.

Parkes, R. J. 2011. Interrupting History: Rethinking History Curriculum after 'The End of History'. New York: Peter Lang Publishing.

Persson, A. 2017. Lärartillvaro och historieundervisning: innebörder av ett nytt uppdrag i de mätbara resultatens tid. Umeå: Umeå universitet.

Persson, A. and R. Thorp. 2017. 'Historieundervisningens existentialiserande potential'. Nordidactica: Journal of Humanities and Social Science Education 2: 59-74.

Porat, D. A. 2004. 'It's Not Written Here, but This is What Happened: Students' Cultural Comprehension of Textbook Narratives on the Israeli-Arab Conflict'. American Educational Research Journal 41, no. 4: 963-996.

Thorp, R. 2016. Uses of History in History Education. Umeå: Umeå universitet.

Wilschut, A. 2012. Images of Time: The Role of an Historical Consciousness of Time in Learning History. Charlotte, NC: Information Age Pub.

Wineburg, S. 2001. Historical Thinking and other Unnatural Acts: Charting the Future of Teaching the Past. Philadelphia: Temple University Press.

Wineburg, S., S. Mosborg, D. Porat and A. Duncan. 2007. 'Common Belief and the Cultural Curriculum: An Intergenerational Study of Historical Consciousness'. American Educational Research Journal 44, no. 1: 40-76 https://doi.org/10.3102/0002831206298677.

Zanazanian, P. 2012. 'Historical Consciousness and the Structuring of Group Boundaries: A Look at Two Francophone School History Teachers Regarding Quebec's Anglophone Minority'. Curriculum Inquiry 42, no. 2: 215-239. 
Open Access This chapter is licensed under the terms of the Creative Commons Attribution 4.0 International License (http://creativecommons.org/licenses/ by/4.0/), which permits use, sharing, adaptation, distribution and reproduction in any medium or format, as long as you give appropriate credit to the original author(s) and the source, provide a link to the Creative Commons licence and indicate if changes were made.

The images or other third party material in this chapter are included in the chapter's Creative Commons licence, unless indicated otherwise in a credit line to the material. If material is not included in the chapter's Creative Commons licence and your intended use is not permitted by statutory regulation or exceeds the permitted use, you will need to obtain permission directly from the copyright holder.

(c) (1) 